\title{
Drivers of diversity and altitudinal distribution of chironomids (Diptera: Chironomidae) in the Ecuadorian Andes
}

\author{
Christian Villamarín ${ }^{1 *}$, Santiago Villamarín-Cortez ${ }^{2,3}$, Danielle M. Salcido², \\ Mauricio Herrera-Madrid ${ }^{3} \&$ Blanca Ríos-Touma ${ }^{1}$ \\ 1. Grupo de Investigación BIOMAS, Facultad de Ingenierías y Ciencias Aplicadas, Universidad de Las Américas, \\ C/ José Queri, Quito, Ecuador; christian.villamarin@udla.edu.ec, blanca.rios@udla.edu.ec \\ 2. Department of Biology, PhD Program in Ecology, Evolution and Conservation, University of Nevada, Reno, Nevada, \\ United States of America; sanbiol@gmail.com, danisalcido@gmail.com \\ 3. Instituto Nacional de Biodiversidad (INABIO), Rumipamba 341 y Av. Shyris, Quito, Ecuador; \\ mauricio.herrera@biodiversidad.gob.ec \\ * Correspondence.
}

Received 03-III-2020. Corrected 15-X-2020. Accepted 04-XI-2020.

\begin{abstract}
Introduction: Chironomids (Diptera: Chironomidae) are the most globally diverse and widely distributed aquatic insects. Despite their prevalence in lotic systems, little is known about the ecology and diversity of tropical species relative to other aquatic insect taxa, particularly at the immature stages. Objective: Characterize chironomid diversity across an elevational gradient in Southwestern Ecuador and water quality parameters associated with their composition. Methods: Samples were collected using a Surber net in forty rivers within four watersheds in the Ecuadorian Andes comprised of montane and dry lowland forest and spanning an elevational gradient of 3120 m.a.s.l. Various physic chemical variables were measured including oxygen, conductivity, total dissolved solids, temperature, and $\mathrm{pH}$. Results: Generally, environmental variables were strongly correlated with the composition of chironomid communities. Variation in the chriomid communities was most strongly associated with oxygen, conductivity and $\mathrm{pH}$. The presence of Parametriocnemus, Cricotopus f4, Cricotopus sp3., Cricotopus (Isocladius), Oliveiriella, Onconeura, Alotanypus and Pentaneura was associated with lower temperatures, high dissolved oxygen and low conductivity while assemblages of Cricotopus sp., Rheotanytarsus, Tanytarsus, and Chironomus were associated with high conductivity and low concentrations of dissolved oxygen. The RELATE analysis showed that local environmental characteristics are determine the composition of the chironomid community. Conclusions: Similarity among local environmental factors was strongly correlated to similarity among Chironomidae assemblages, especially with variables such as oxygen concentration, $\mathrm{pH}$ and conductivity, whose variables are highly correlated to land use and dominant vegetation in the watersheds sampled.
\end{abstract}

Key words: Tropical Andes; environmental variables; diversity patterns.

Villamarín, C., Villamarín-Cortez, S., Salcido, D.M., Herrera-Madrid, M., \& Ríos-Touma, B. (2021). Drivers of diversity and altitudinal distribution of chironomids (Diptera: Chironomidae) in the Ecuadorian Andes. Revista de Biología Tropical, 69(1), 113126. DOI $10.15517 /$ rbt.v69i1.40964

Chironomidae is one of the most widely distributed families of aquatic Diptera spanning broad latitudinal, altitudinal, and disturbance gradients (Ashe, Murray, \& Reiss, 1987). Species within this group are able to survive a suite of extreme conditions including freezing temperatures, saline-rich or oxygenpoor waters. Extraordinary examples include species that inhabit extreme freezing, hypoxic or saline environments such as Antarctica, swamps, brackish water and sewers (Lencioni, Cranston, \& Makarchenko, 2018) via a suite 
of protein adaptations such as hemoglobinlike respiratory proteins or heat shock proteins (Hanson, Springer, \& Ramirez, 2010). Both the immature and adult stages of their lifecycle, make this group extremely important to aquatic food webs as sources of proteins, lipids and minerals for fish, amphibians, birds and other macroinvertebrates (Armitage, Cranston, \& Pinder, 1995).

While these familiar examples highlight taxa capable of living in extreme environments, the majority of species have specific habitat requirements (Lencioni et al., 2018). Species are sensitive to subtle changes in water quality and serve as indicators of stream health in freshwater biomonitoring assessments (Paggi, 2003). In addition, individual-level morphological features such as teeth deformities can indicate specific water contaminates (Roback \& Coffman, 1983; Ossa et al., 2018). Pollution from mining and agriculture have altered the physical, chemical and biotic environment of aquatic systems, especially in the Neo-tropics (Villamarín, Prat, \& Rieradevall, 2014). These result in changes to nutrient and sedimentation inputs, flow rate, thermal environment and biotic introductions (Ríos-Touma \& Ramírez, 2019) with implications for the macroinvertebrate communities and functional diversity (Prat, Ríos-Touma, Acosta, \& Rieradevall, 2009).

In Ecuador, most Chironomidae research focuses on systematics and for the subset that address ecology, identifications are resolved to family-level morphotypes (Ríos-Touma, Acosta, \& Prat, 2014; Encalada et al., 2019). Given the importance and diversity of this family in aquatic environments, it is critical to advance the knowledge with species-level resolution in an ecological context to understand how environmental stressors modify these communities. Previous studies in the Andean ranges focus on Northern (Oviedo-Machado \& Reinoso-Flórez, 2018) and Central Andes (Acosta \& Prat, 2010) and have shown differences in subfamily composition across elevational cline. Dominant subfamilies at higher elevations include Orthocladiinae, Podonominae and Diamesinae, while lower elevations Chironominae and
Tanypodinae dominate indicating the role of elevation, temperature and stream physical characteristics in structuring these communities (Acosta \& Prat, 2010; Oviedo-Machado \& Reinoso-Flórez, 2018).

Southern Ecuador exhibits exceptional endemism (Mittermeier, Myers, Thomsen, da Fonseca, \& Olivieri, 1998) and is a biodiversity hotspot (Mittermeier et al., 1998) in part because of the several unique ecoregions, proximity to arid and semi-arid areas of Northern Perú (Sierra, 1999) and the Andean depression (also known as the Depression of Huancabamba) a valley separating the central Andes from the Northern (Villamarín, Rieradevall, \& Prat, 2020). Despite the extreme endemism of this region, studies characterizing aquatic macroinvertebrate fauna, particularly among Chrironomidae, are scarce. Understanding environmental factors shaping chironomid diversity is particularly important as rivers in the region are continually impacted by land-use change (Ríos-Touma \& Ramírez, 2019). Here we analyze how elevation and environmental gradients shape the Chironomid community composition in four watersheds of Southwestern Ecuador to understand the environmental drivers of the diversity of this important aquatic group.

\section{MATERIALS AND METHODS}

Study Area: The study took place at El Oro Province, in Southwestern Ecuador. This region has marked seasonality, a dry season (June-October) and wet season (DecemberMay) (Escribano-Ávila, 2016). The samples were taken only in dry season to minimize the environmental variability that could destabilize the chironomid community. Within the province we sampled from four watersheds (Fig. 1, Table 1): Puyango (3394 km² 0-3 285 m), Santa Rosa (2805 km², 0-2 900 m), Jubones $\left(2153 \mathrm{~km}^{2}, 0-3900 \mathrm{~m}\right)$ and Siete $\left(1411 \mathrm{~km}^{2}\right.$, 0-3120 m) (Villamarín \& Villamarín-Cortez, 2018). Forty rivers were sampled total during the dry season between 2015 and 2016 (Fig. 1). The elevation gradient of sample sites 


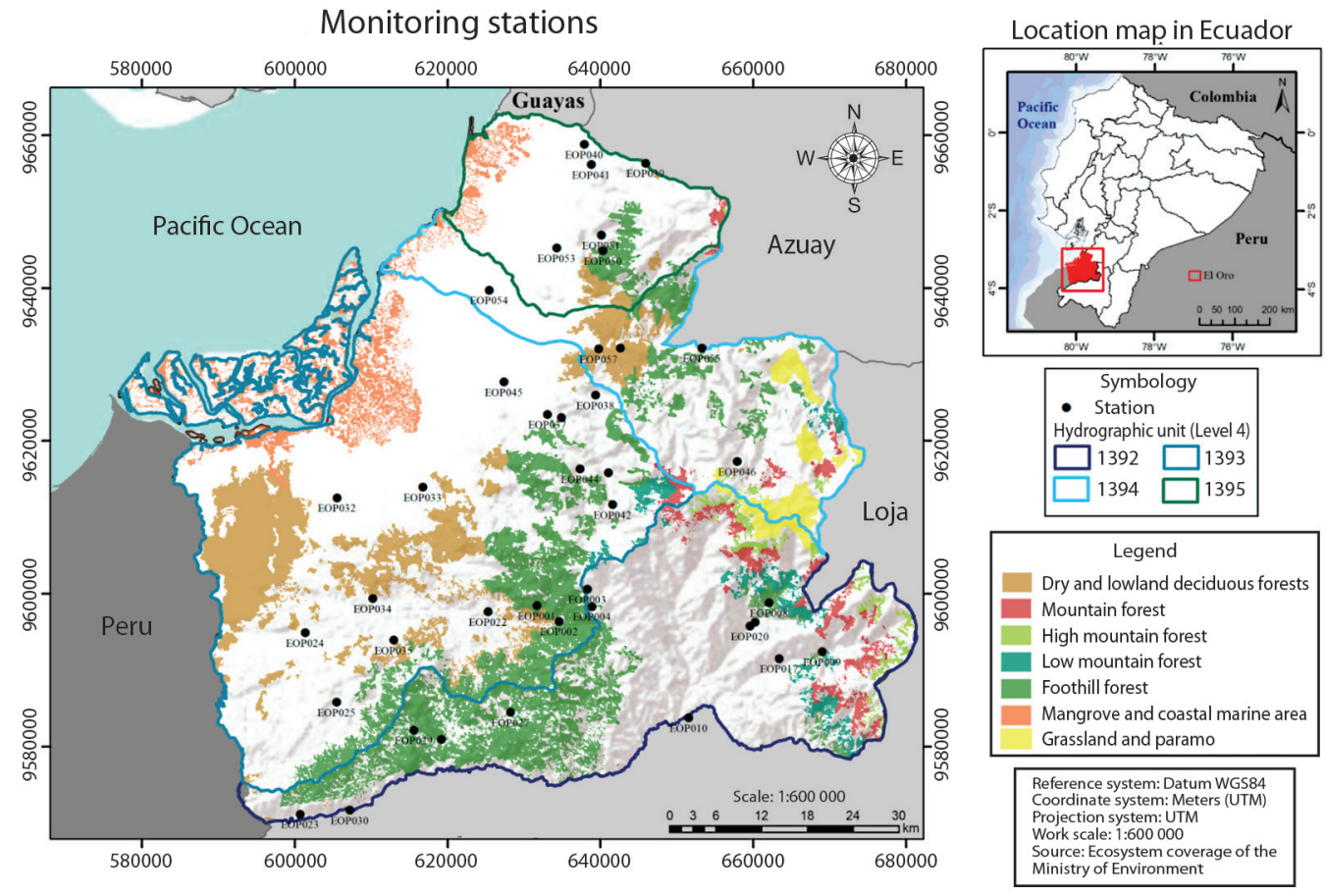

Fig. 1. Sampling sites location in Southwest Ecuador. Basin and biomes information of each site is included.

ranged between 10 to $2427 \mathrm{~m}$ and varied in their degree of disturbance (ie. not impacted to highly impacted). For the analyses we defined three elevation bands: low (16 to $300 \mathrm{~m} ; \mathrm{N}=17$ rivers), mid (301 to $1000 \mathrm{~m} ; \mathrm{N}=14$ ) and high $(>1001 \mathrm{~m} ; \mathrm{N}=9)$.

Sampling and measurement of environmental variables: We collected abiotic samples using a $0.11 \mathrm{~m}^{2}$ Surber net with 280-micron mesh light standardized at $1 \mathrm{~m}^{2}$ (Manson, Wallis, \& Hope, 2001). Nine benthic samples were collected at each site and stored in $96 \%$ alcohol. Samples were separated into families at the National Institute of Biodiversity (INABIO) and taxonomic identifications were made at the Research Laboratory of the Universidad de Las Américas (UDLA) following the nomenclature published in chironomids specialized guides (Ruiz-Moreno, Ospina-Torres, Gómez-Sierra, \& Riss, 2000; Ruíz-Moreno, Ospina-Torres, \& Riss, 2000; Epler, 2001; Prat, Rieradevall, Acosta, \& Villamarín, 2011).
We prepared plate mounts following the methodology proposed by Epler (2001) to designate chironomids morpho species.

Measurements of the chemical and physical parameters, hereafter referred to as environmental variables, were collected in situ at each sample site using a HACH multi-metric probe (Loveland, CO, USA). We measured temperature, dissolved oxygen, conductivity, total dissolved solids and $\mathrm{pH}$. Due to significant correlations among environmental variables, we did not include measurements of total dissolved solids and temperature analyses.

Principal Component Analysis of environmental parameters for each elevational band: To understand the environmental factors associated with variation in elevation we applied Principal Component Analysis (PCA) (Clarke \& Gorley, 2006). PCA effectively reduces the dimensionality of covarying variables without loss of information thereby improving the interpretation of the results 
TABLE 1

Description of each studied site (river name, code, coordinates, altitude, biome) at of El Oro province, Ecuador

\begin{tabular}{|c|c|c|c|c|}
\hline Códe & River Name & Coordinates WGS84 (UTM) & Altitude (masl) & Biome \\
\hline EOP001 & Riachuelo S/N Buenaventura 1 & $631698 / 9598507$ & 1124 & Foothill forest \\
\hline EOP002 & Río El Placer & $634599 / 9596436$ & 1311 & Foothill forest \\
\hline EOP003 & Riachuelo S/N Buenaventura 2 & 638334 / 9600616 & 1095 & Foothill forest \\
\hline OP004 & Río Buenaventura & 638934 / 9598359 & 1003 & Foothill forest \\
\hline EOP008 & Río Elvira & 662069 / 9598826 & 1065 & Foothill forest \\
\hline EOP009 & Río San Luis & 669052 / 9592458 & 1472 & Foothill forest \\
\hline EOPO10 & Río Pindo & $651584 / 9583798$ & 562 & Foothill forest \\
\hline EOPO14 & Río Amarillo & $660240 / 9596314$ & 946 & Foothill forest \\
\hline EOP017 & Riachuelo 3 Guizhaguiña & $663410 / 9591554$ & 1282 & Foothill forest \\
\hline EOP020 & Riachuelo 3 Guizhaguiña & $659573 / 9595804$ & 907 & Foothill forest \\
\hline EOP022 & Río Naranjo & $625313 / 9597675$ & 162 & Dry lowlands forest \\
\hline EOP023 & Quebrada Los Sábalos & $600736 / 9571197$ & 315 & Dry lowlands forest \\
\hline EOP024 & Río Palmales & 601406 / 9594922 & 73 & Dry lowlands forest \\
\hline EOP025 & Quebrada del Gallo & $605506 / 9585837$ & 338 & Dry lowlands forest \\
\hline EOP027 & Río Balsas & $628257 / 9584535$ & 598 & Foothill forest \\
\hline EOP028 & Río Marcabelí & 619227 / 9580988 & 499 & Foothill forest \\
\hline EOP029 & Río Aguas Negras & $615636 / 9582190$ & 561 & Foothill forest \\
\hline EOP030 & Río Puyango & $607225 / 9571745$ & 308 & Dry lowlands forest \\
\hline EOP032 & Río S/N (sector la Cuca) & $605536 / 9612584$ & 10 & Dry lowlands forest \\
\hline EOP033 & Río Santa Rosa & 616778 / 9613980 & 33 & Dry lowlands forest \\
\hline EOP034 & Río Arenillas & $610219 / 9599417$ & 16 & Dry lowlands forest \\
\hline EOP035 & Río Blanco & 612989 / 9593984 & 140 & Dry lowlands forest \\
\hline EOP036 & Río Raspas & 634907 / 9623093 & 62 & Dry lowlands forest \\
\hline EOP037 & Río San Agustín & 633089 / 9623505 & 50 & Dry lowlands forest \\
\hline EOP038 & Río Palenque & 639395 / 9626001 & 90 & Dry lowlands forest \\
\hline EOP039 & Río Siete & $645910 / 9656355$ & 339 & Foothill forest \\
\hline EOP040 & Río Pagua & 637895 / 9658807 & 20 & Dry lowlands forest \\
\hline EOP041 & Río Bonito & $638800 / 9656191$ & 38 & Dry lowlands forest \\
\hline EOP042 & Río S/N (sector Cerro Azul) & $641597 / 9611712$ & 1131 & Foothill forest \\
\hline EOP043 & Río Chilola & $641029 / 9615874$ & 467 & Foothill forest \\
\hline EOP044 & Río Dumari & $637322 / 9616378$ & 267 & Dry lowlands forest \\
\hline EOP045 & Río Buenavista & $627402 / 9627751$ & 25 & Dry lowlands forest \\
\hline EOP046 & Río Pivir & $657912 / 9617313$ & 2427 & Montane forest \\
\hline EOP049 & Río Casacay & $642629 / 9632185$ & 116 & Dry lowlands forest \\
\hline EOP050 & Río Colorado & 640334 / 9644898 & 205 & Dry lowlands forest \\
\hline EOP051 & Río San Jacinto & $640162 / 9646942$ & 126 & Dry lowlands forest \\
\hline EOP053 & Río Changana & $634296 / 9645282$ & 14 & Dry lowlands forest \\
\hline EOP054 & Río Jubones & 625443 / 9639749 & 28 & Dry lowlands forest \\
\hline EOP055 & Río Cune & $653296 / 9632175$ & 349 & Foothill forest \\
\hline EOP057 & Río Huizho & $639771 / 9632039$ & 63 & Dry lowlands forest \\
\hline
\end{tabular}

Vegetation in the low-elevation band consists of lowland dry forest and lowland deciduous forests (Sierra, 1999). Defining characteristics of rivers in this band include stony substrates, silt, and sand with a strong flow rate. Evergreen forests dominate the mid-elevation band (Sierra, 1999), and rivers have a lower proportion of sand than those rivers located in the low-elevation band. At high elevation, evergreen forests dominate and rivers have a relatively slower flow rate. Upper basin areas are comprised of well-preserved and minimally disturbed forest (Villamarín \& Villamarín-Cortez, 2018) while mid and lower elevations within the drainages have a high degree of agricultural exploitation and urban development. 
(Jollife \& Cadima, 2016). The PCA was performed in Primer6 (Clarke \& Warwick, 1994).

Calculating Chironomid Diversity: Estimates of diversity were calculated at the genus level using Hill numbers (Chao et al., 2014; Chao \& Jost, 2015). Values for diversity ( $\left.{ }^{\mathrm{g} D}\right)$ can be interpreted as the effective number of chironomid genera. Hill numbers of order $q$ represent richness $(\mathrm{q}=0)$, exponential of Shannon's entropy ( $q=1)$ and the inverse Simpson concentration $(q=2)$. Results are illustrated as a continuous function of the parameter $q$ (Chao \& Jost, 2015). The analysis was performed in the iNext interactive web application (Hsieh, Ma, \& Chao, 2016).

Evaluating associations among Chironomidae community and environmental factors: To determine the relationship between chironomid community assembly and environmental variables, we performed a Canonical Correspondence Analysis (CCA) using CANOCO software (Braak Ter \& Barendregt, 1998). This technique determines the linear combination of environmental variables and community data that maximizes their correlation (Borcard, Gillet, \& Legendre, 2011) and species order along the canonical axes indicates their ecological optimum (Borcard et al., 2011). Statistical significance was evaluated using a Monte Carlo permutation procedure (9999 permutations) (Braak Ter \& Barendregt, 1998). Species ranking in the bottom $10 \%$ of abundances were removed prior to analysis to prevent noise from rare taxa.

To understand genera-level contributions to Bray-Curtis similarities among each elevational band, we performed a percentage of similarity analysis (SIMPER; PRIMER6) (Clarke \& Warwick, 1994).

To understand the relationship among distance, elevation and environmental variables on community composition, we applied a Spearman rank correlation to the environmental and biological dissimilarity matrices and tested the statistical significance using randomly permuted matrices (RELATE; 9999 permutations; Primer 6). Previously, the environmental variables were normalized, while the biological data were transformed using $\log (\mathrm{x}+1)$, the distance and the elevation data were not transformed. Three environmental dissimilarity matrices were constructed using environmental variables and site-level differences in geographic distance and elevation. The community similarity matrix was comprised of abundances of chironomid morphospecies. Dissimilarities among environmental variables were calculated using Euclidean distances while Bray-Curtis similarity was applied to the community matrix.

\section{RESULTS}

Environmental Variables: Environmental variables exhibited substantial variation among the three elevation bands (Table 2). Across all elevational bands $\mathrm{pH}$ was consistently neutral with little variation. Unusually high dissolved oxygen content at low elevations was observed in select sites such that mean values indicate hyperoxic conditions. Conductivity was relatively low at higher elevations and highest at mid elevation, especially in sites exposed to runoff from agriculture. Similarly, total dissolved solids were highest at lower elevations. As expected, temperature was negatively correlated with the elevation.

The first principal component (PC1) explained $37 \%$ of the variance and dissolved oxygen and conductivity weighed most heavily (Fig. 2, Table 3). The second principal component (PC2) explained $29.6 \%$ of the variance and $\mathrm{pH}$ and elevation weighed most heavily. In general, higher loadings on PC1 and PC2 are indicative of healthier aquatic environments. Variation in samples from rivers in higher elevations was attributed to variation in PC2, whereas samples from middle elevations varied more along PC1. Samples from low elevation sites exhibited substantial variation across both axes (Fig. 2).

Patterns in Chironomidae Abundance \& Diversity: For the three common subfamilies, 
TABLE 2

Mean values and standard deviations (SD) of environmental variables measured from studied sites at el Oro province in Southwestern Ecuador

\begin{tabular}{lcccccc} 
& \multicolumn{2}{c}{ Low elevation $\mathrm{N}=17$} & \multicolumn{2}{c}{ Middle elevation $\mathrm{N}=14$} & \multicolumn{3}{c}{ High elevation $\mathrm{N}=9$} \\
\multicolumn{1}{c}{ Environmental Variables } & Mean & $\mathrm{SD}$ & Mean & $\mathrm{SD}$ & Mean & $\mathrm{SD}$ \\
Elevation (m.a.s.1.) & 62.7 & 48.1 & 475.8 & 225.7 & 1323.3 & 438.8 \\
$\mathrm{PH}$ & 7.3 & 0.5 & 7.1 & 0.3 & 7.4 & 0.5 \\
Dissolved Oxygen $(\mathrm{mg} / \mathrm{L})$ & 13.8 & 6.7 & 11.4 & 2.7 & 12.2 & 1.8 \\
Conductivity $(\mu \mathrm{S} / \mathrm{cm})$ & 122.9 & 86.2 & 646.0 & 293.5 & 71.5 & 24.3 \\
Temperature $\left({ }^{\circ} \mathrm{C}\right)$ & 25.1 & 2.0 & 23.0 & 2.3 & 19.6 & 2.3 \\
Total Dissolved Solids $(\mathrm{mg} / \mathrm{L})$ & 58.0 & 42.3 & 39.9 & 21.2 & 33.7 & 11.7 \\
\hline
\end{tabular}

TABLE 3

Factor loadings and variance explained from Principal Component Analysis (PCA) on environmental variables from the studied sites at El Oro province, in Southwestern Ecuador

\begin{tabular}{lcc} 
& PC 1 & PC 2 \\
\% Variance of each component & 37 & 29.6 \\
\% Accumulated Variance & 37 & 66.5 \\
Variables & & \\
$\quad$ Elevation & 0.284 & $\mathbf{0 . 5 6 1}$ \\
pH & 0.388 & $\mathbf{- 0 . 5 4 8}$ \\
$\quad$ Dissolved Oxygen & $\mathbf{0 . 6 5 6}$ & -0.364 \\
$\quad$ Conductivity & $\mathbf{- 0 . 5 8 1}$ & $\mathbf{- 0 . 5 0 3}$ \\
\hline
\end{tabular}

densities at higher elevation were consistently lower densities than densities at lower elevation (Fig. 3A). For the three elevation gradients, Chironominae was the most abundant subfamily, with a marked increase at mid-elevations. Tanypodinae was consistently the least abundant subfamily across elevation gradients. In contrast, Chironominae was the most abundant in lower-elevation rivers.

There were 37 unique Chironomid genera sampled and the greatest richness was observed at high elevations $\left({ }^{0} \mathrm{D}=30\right)$ followed by low elevation $\left({ }^{0} \mathrm{D}=30\right)$ and mid elevation $\left({ }^{0} \mathrm{D}=26\right)$
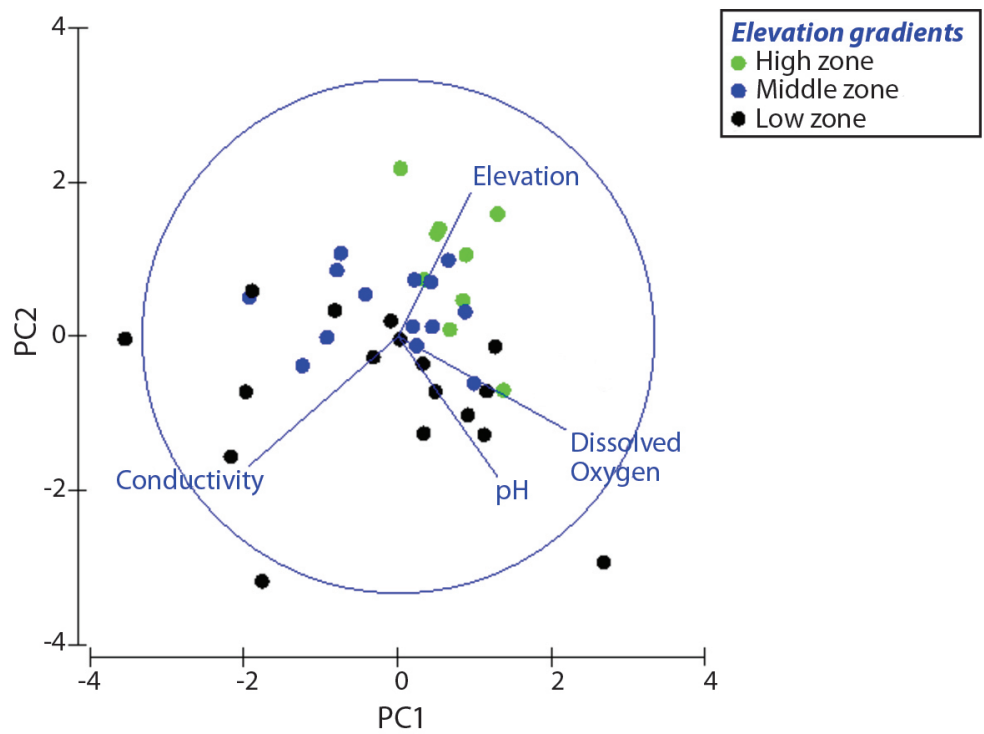

\section{4}

Fig. 2. PCA of the environmental variables and rivers from Southwestern Ecuador. The green dots correspond to the rivers from higher elevations, the blue dots correspond to the rivers in the middle elevation, and the black dots to rivers from lower elevations. 

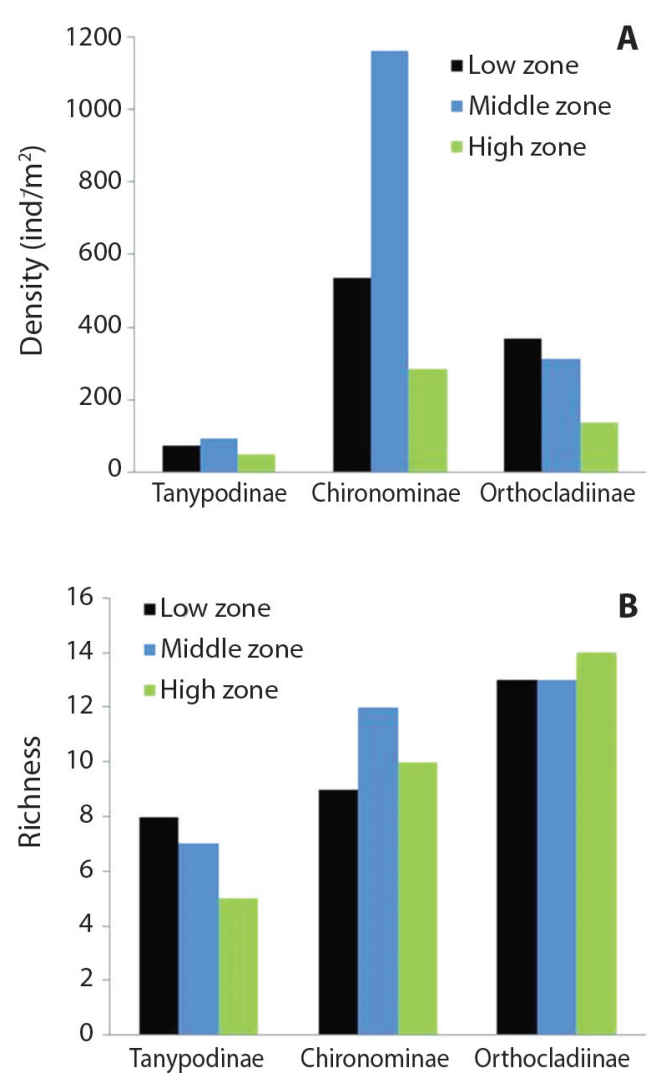

Fig. 3. A. Chironomids subfamilies densities of high, middle, and low elevations from Southwestern Ecuador. B. Chironomid subfamilies richness from Southwestern Ecuador. The green bars correspond to high elevation rivers; the blue ones correspond to mid-elevation rivers and the black ones to low elevation rivers.

(Fig. 4). Patterns of diversity were similar to patterns of richness except for measures of Simpson diversity for the low elevation (high: $\mathrm{q}_{1}=9.55, \mathrm{q}_{2}=4.99 ;$ mid: $\mathrm{q}_{1}=7.2, \mathrm{q}_{2}=4.14$; low: $\mathrm{q}_{1}=7.86 ; \mathrm{q}_{2}=3.92$ ). However, differences in diversity between the elevation categories were not significant $(\mathrm{F}=0.024, \mathrm{DF}=2, \mathrm{P}>$ $0.05)$. The most dominant subfamilies included Orthocladiinae (18 genera), Chironominae (11 genera), and Tanypodinae (8 genera). Patterns of richness for the most representative subfamilies varied by elevation (Fig. 3B). Orthocladiinae was well represented across all rivers, but the greatest richness was found in rivers at higher elevation $(>1000 \mathrm{~m})$. Chironominae richness was highest at mid-elevation, followed by Orthocladiinae, and Tanypodinae. The occurrence of Tanypodinae and Orthocladiinae decreased with increasing elevation.

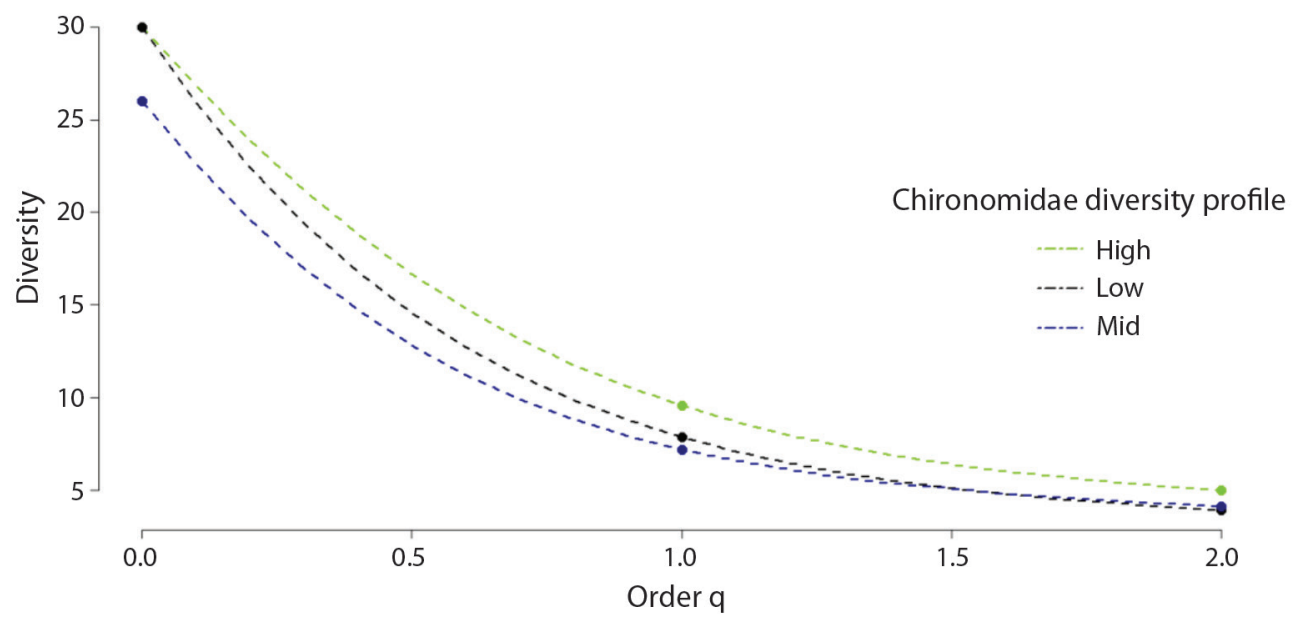

Fig. 4. Diversity observed using Hill numbers $\left(\mathrm{q}_{0}=\right.$ Richness, $\mathrm{q}_{1}=$ Shannon diversity and $\mathrm{q}_{2}=$ Simpsons Diversity $)$ from Southwestern Ecuador. Green dotted lines correspond to rivers of the high elevations; blue dots correspond to rivers of middle elevations, and black dots correspond to rivers of low elevations. 

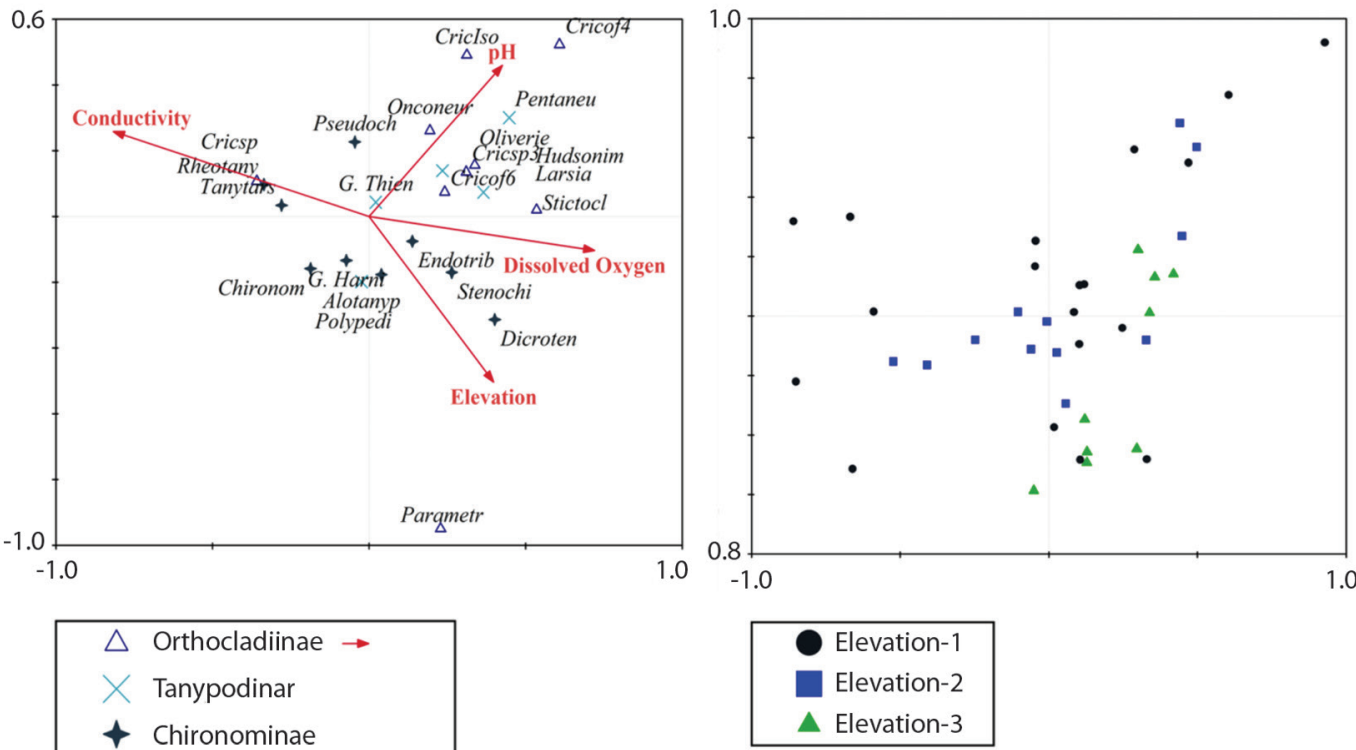

Fig. 5. CCA of the environmental variables and genera of the Chironomidae family A. $\mathbf{\Delta}$ : Othocladiinae genus; $\mathrm{x}$ : Tanypodinae genus; +: Chironominae genus. B. $\mathbf{\Delta}$ : correspond to the locations of the upper elevation range; $\mathbf{m}$ : to those of the middle elevation range and $\bullet$ : of the lower elevation range).

Tanypodinae was present in low densities at the three elevation bands. Orthocladiinae richness and density showed a clear trend to increase with the elevation.

\section{Relationships among Chironomidae} community and environmental variables: In the Canonical Correspondence Analysis (CCA), conductivity and dissolved oxygen weighed heavily on the first axis, while $\mathrm{pH}$ and elevation weighed on the second axis (Fig. 5A). Rivers with high dissolved oxygen concentrations, and low conductivity values are associated with the abundance of Parametriocnemus, Cricotopus f4, Cricotopus sp3., Cricotopus (Isocladius), Oliveiriella, Onconeura, Alotanypus, and Pentaneura (Fig. 5A). Rivers characterized by high conductivity values, and low oxygen dissolved concentrations are associated with Cricotopus sp., Rheotanytarsus, Tanytarsus, Chironomus and Group Harnischia. While several genera showed a preference for particular environmental conditions, others showed no preference, primarily those generally distributed throughout the environmental gradient such as Polypedilum, Oliveiriella, Cricotopus f6, Hudsonimyia, Rheotanytarsus and Larsia (Fig. 5A). The distribution of the sampling sites in the ACC shows that the composition of the chironomid community is influenced mainly by the local characteristics of each site since it does not show a significant separation in the two-dimensional plane (Fig. 5B).

Spearman rank correlations (RELATE) among Chironomid communities and water quality parameters were not strongly nor significantly correlated $(\mathrm{P}=0.113 ; \mathrm{P}=0.0963)$. Similarly, geographical distance $(\mathrm{P}=0.049 ; \mathrm{P}=$ 0.2267) and elevation $(\mathrm{P}=0.042 ; \mathrm{P}=0.6976)$ did not exhibit significant correlation to chironomid community composition. The analyses conducted in each elevation band do not show correlation with the environmental characteristics. Nevertheless, the Low Band ( $\mathrm{P}=0.098 ; \mathrm{P}$ $=0.217$ ) had a better correlation, followed by the High band $(\mathrm{P}=0.056 ; \mathrm{P}=0.381)$ and the Mid Band $(\mathrm{P}=-0.079 ; \mathrm{P}=0.742)$.

The SIMPER analysis revealed similar distribution patterns to de CCA specially in the dominant genera as is the case of Polypedilum, 
TABLE 4

SIMPER (Percentage of Similarity) analysis results for genus among studied sites grouped by elevation bands. In bold are the values of the percentage of contribution of each genus to the similarity among sites of the same elevation band

\begin{tabular}{|c|c|c|c|}
\hline & Low elevation sites & Middle elevation sties & High elevation sites \\
\hline Similarity & 18.89 & 23.9 & 16.11 \\
\hline Genus & $\%$ Contrib. & $\%$ Contrib. & $\%$ Contrib. \\
\hline Polypedilum & 27.02 & 29.39 & 30.41 \\
\hline Tanytarsus & 6.62 & 6.83 & 5.98 \\
\hline Pseudochironominii & 4.2 & 9.75 & 4.29 \\
\hline Dicrotendipes & 3.99 & - & - \\
\hline G. Harnischia & 3 & 1.28 & 3.06 \\
\hline Stenochironomus & 1.83 & 0.83 & 0.95 \\
\hline Chironomus & - & 0.16 & 0.61 \\
\hline Rheotanytarsus & - & 9.44 & 8.5 \\
\hline Endotribelos & 4.37 & - & - \\
\hline Cricotopus sp. & 17.65 & 8.38 & 6.15 \\
\hline Oliveriella & 5.17 & 3.96 & 2.16 \\
\hline Parametriocnemus & 3.66 & - & - \\
\hline Stictocladius & 2.57 & - & - \\
\hline Género 1 & 1.01 & - & - \\
\hline Cricotopus sp3. & 0.69 & 0.47 & 5.45 \\
\hline Cricotopus (Isocladius) & - & 2.86 & 0.2 \\
\hline Cricotopus $\mathrm{f} 4$ & - & - & 1.76 \\
\hline Cricotopus f6 & - & 0.62 & - \\
\hline Onconeura & - & - & 0.84 \\
\hline Larsia & 12.74 & - & 12.2 \\
\hline G. Thienemannimyia & 2.7 & 12.03 & 6.24 \\
\hline Alotanypus & 2.27 & 11.28 & 6.79 \\
\hline Pentaneura & 0.5 & 0.77 & 3.69 \\
\hline Hudsonimyia & - & 1.96 & 0.73 \\
\hline
\end{tabular}

Chironomus, Group Harnischia, Cricitopus, Tanytarsus (Table 4).

\section{DISCUSSION}

There is a strong influence of elevation and conductivity on rivers from Southwestern Ecuador. Elevation also tends to be associated, directly and indirectly, with other environmental components such as the productivity, composition of the river bed substrate and vegetation, type of allochthonous material inputs from adjacent ecosystem, and structure of the river channel (Scheibler, Pozo, \& Paggi, 2008; Acosta \& Prat, 2010; Oviedo-Machado \& Reinoso-Flórez, 2018). While the variables mentioned were not measured in our study, our analyses reveal high environmental variation that could influence both, biotic and abiotic components, and define the composition and structure of the chironomid community, especially variables that change along the gradient.

The positive relationship between temperature and elevation is to be expected and in turn affects processes of decomposition. In lower elevations, microbial activity tends to be higher (Acosta \& Prat, 2010), which has implications on measured environmental variables and the biological communities that inhabit the rivers. Further, biomes in lower elevations are predominantly dry (Briceño, Iniguez-Gallardo, \& Ravera, 2016; Escribano-Ávila, 2016) and 
inputs of allochthonous material differ from those of the highlands, where the riparian forest vegetation contributes to high and continuous inputs of organic matter.

It is well known that temperature is a strong driver for the distribution of macroinvertebrates along latitudinal and elevational gradients (Dos Santos et al., 2018; Prat et al., 2018). The distribution of chironomids has been associated with temperature gradients elsewhere (Acosta \& Prat, 2010) including Oliveiriella, Paraheptagya, Limaya and Parochlus (Prat et al., 2011; Prat et al., 2018). In our case, Chironominae was the most frequent and dominant subfamily rivers at lower elevations while Orthocladiinae was more prevalent in rivers at higher elevations. Temperature is also strongly associated with oxygen solubility (Jacobsen, 2003; Verberk, Bilton, Calosi, \& Spicer, 2011) such that the high-temperature recorded in low elevation bands explain dissolved oxygen results in rivers sampled at lower elevations. The considerable decrease in oxygen at low elevation sites could be attributable to the quantity of fine sediments with a high organic load (López \& Talero, 2015; Prat et al., 2018; Sierpe \& Sunico, 2019) and while unusually high levels of dissolved oxygen at other sites may be the result of eutrophication (Harper \& Phillips, 1992; Benjumea \& Wills, 2007; Minaudo, Meybeck, Moatar, Gassama, \& Curie, 2015).

High and low elevation areas have similar Chironomidae richness. Diversity was greatest at high elevations due to the higher abundance of more common species which is likely attributable to the greater water quality. At lower elevations, the diversity of rare or unique species is virtually zero compared to the other elevations. In these lower sites we found species capable of withstanding high temperatures or reduced oxygen which indicates either adaptations or phenotypic plasticity. Also, at lower elevations, less geographical barriers are found, which can contribute to a wider distribution of the species. Rivers at low elevations are impacted by inputs from agricultural, urban and mining practices especially gold extraction (Villamarín \& Villamarín-Cortez, 2018). We observed reduced diversity at midelevation with much more stable communities and unique genera relative to low-lying areas.

Studies in Ecuador are limited on this taxonomic group and still under study (Roback \& Coffman, 1983; Prat, Acosta, Villamarín, \& Rieradevall, 2018; Hamerlik, da Silva, \& Jacobsen, 2019), a recent research by Hamerlik et al. (2019), identified 16 genera in the upper Andean area of the Antisana Volcano compared to the 30 genera found in our study. Consequently, lowlands of the Andes can hold a higher diversity of chironomids.

At subfamily level, we observed changes in richness, abundance and diversity along the elevation gradient, being Chironominae the most dominant subfamily at lower elevations, characterized by lower dissolved oxygen content and dominance of fine sediments with high organic content (Acosta \& Prat, 2010; López \& Talero, 2015).

While distribution patterns of subfamilies have already been described, few studies take place at genus level. We show that taxonomic resolution reveals distinctive patterns of chironomid distribution along elevation gradients. Our results suggest a clear turnover pattern of dominant groups along the elevation gradient considering the subfamily taxonomic level as a boundary. However, several genera showed specific preferences for particular environmental conditions.

Orthocladiinae was more diverse at high elevations. This might be due to the rocky substrate, periphyton developed in rocks, low or medium flow rates with steeper slopes, which increases oxygen availability in rivers at higher elevations. Hence, the trend of subfamily composition relates to elevation, temperature, dissolved oxygen, and total dissolved solids. Therefore, different larvae morphotypes of Cricotopus, Parametriocnemus, Oliveiriella and Stictocladius, were mainly found on high-elevation sites, which are characterized by rivers with lower temperatures and stable flow channels (Acosta \& Prat, 2010; Hamerlik et al., 2019); with rock and pebble substrates 
(Oviedo-Machado \& Reinoso-Flórez, 2018) and fed mainly on algae and fine particulate matter (Caleño, Rivera-Rondon, \& Ovalle, 2018; Oviedo-Machado \& Reinoso-Flórez, 2018).

The subfamily Chironominae tends to increase its richness and abundance at lower elevation areas (Acosta \& Prat, 2010). As a consequence, some genera have developed adaptations, such as hemoglobin generation, to optimize the use of limited amount of oxygen available in these rivers (OviedoMachado \& Reinoso-Flórez, 2018). As the elevation decreases, environmental characteristics changed in our study sites. In lower elevation areas, temperature, flow, conductivity, and dissolved solids increase. The increase in water temperature reduces the availability of dissolved oxygen, resulting in an increase in chironomid genera with adaptations to these conditions. The genera Chironomus, Stenochironomus, Tanytarsus, Rheotanytarsus, and Polypedilum were dominant in lower-elevation rivers. Several of them are considered tolerant to low dissolved oxygen in water (López \& Talero, 2015) and generally inhabit pool areas where fine sediment accumulates (Caleño et al., 2018). A clear example of this is the proximity found by in the CCA of the genera Tanytarsus and Rheotanytarsus to localities with high concentrations of conductivity, which correlated with the total dissolved solids, that tend to accumulate in river pools as they use this type of substrate to build houses (Caleño et al., 2018; Oviedo-Machado \& Reinoso-Flórez, 2018; Prat \& García-Roger, 2018).

On other hand, there are changes in the composition and abundance community whiles the elevation increase. That is the case of Tanypodinae that depends on the availability of prey as they are predators of other macroinvertebrates or other chironomids (Caleño et al., 2018). Genera such as Alotanypus and Thienemannimyia (Subfamily Tanypodinae) were more abundant in areas with high dissolved solids while Hudsonimyia, Larsia, and Pentaneura seem to have preferences for sites with less dissolved solids at higher-elevation.
Tanypodins are known to be carnivorous chironomids with a preference for macroinvertebrates and animals (Caleño et al., 2018). Therefore, their distribution relates to both environmental characteristics and food availability. While tanypodins are predators, there are some species that consume two types of food (they feed on detritus and diatoms) when prey is scarce (Da Silva \& Ekrem, 2016).

In conclusion, the composition of the chironomid community showed changes in relation to the local environmental characteristics measured, acting as a diversity driver of the composition of Chironomidae. Chironomids have a high dependence on local environmental factors such as dissolved oxygen, $\mathrm{pH}$, conductivity, and elevation. Nevertheless, the elevation and temperature were the most important factors determining the chironomid community composition. Moreover, the elevation acted as a biogeographical barrier, with certain genera restricted to high areas and others in low-lying areas. Additionally, higher elevations are more diverse due to a combination of environmental characteristics and better-preserved drainages.

Ethical statement: authors declare that they all agree with this publication and made significant contributions; that there is no conflict of interest of any kind; and that we followed all pertinent ethical and legal procedures and requirements. All financial sources are fully and clearly stated in the acknowledgements section. A signed document has been filed in the journal archives.

\section{ACKNOWLEDGMENTS}

This study was conducted within the framework of the project "Development of Guides of Mammals, Fish, Aquatic Macroinvertebrates and Flora with emphasis on Orchids and Bromeliads of el Oro Province" proposed by the GAD of el Oro and the INABIO and the project AMB.CVF.17.03 from the University of the Americas, Ecuador. Special thanks to the Ministry of Environment of Ecuador for providing the necessary permits 
(No. 004-IC-FLO-FAU-DPAEO-ME) for the development of this project. To Nacís Prat for the taxonomic review of the samples. To Mateo Vega for the support in the generation of maps, Daniel Padilla-Jiménez, Juan Manuel Guerra, Nicole Cerón, Angie Ramírez, Daniel Donoso, Carlo Escobar, Trujillo Sofía, Stephanie Flores, Freddy Narváez, Alisson Pérez, and Andrea Vaca for their support in the work of laboratory and field.

\section{RESUMEN}

Controladores de diversidad y distribución altitudinal de quironómidos (Diptera: Chironomidae) en los Andes ecuatorianos. Introducción: Los quironómidos (Diptera: Chironomidae) son los insectos acuáticos de mayor diversidad y distribución mundial. A pesar de su prevalencia en los sistemas lóticos, se sabe poco acerca de su ecología y diversidad, especialmente de especies tropicales en relación con otros taxones de insectos acuáticos, particularmente en etapas inmaduras. Objetivo: Caracterizar la diversidad de quironómidos a través de un gradiente altitudinal en el suroeste de Ecuador, además de identificar los parámetros fisicoquímicos asociados con su composición. Métodos: Las muestras se recolectaron utilizando una red Surber en cuarenta ríos dentro de cuatro cuencas hidrográficas en los Andes Sur del Ecuador, en ecosistemas de bosques montanos y secos de tierras bajas abarcando un gradiente altitudinal de 3120 m.s.n.m. Se midieron las variables fisicoquímicas: oxígeno, conductividad, sólidos disueltos totales, temperatura y $\mathrm{pH}$. Resultados: En general, las variables ambientales se correlacionaron fuertemente con la composición de las comunidades de quironómidos. La variación en la comunidad de quironómidos se asoció fuertemente con el oxígeno, la conductividad y el $\mathrm{pH}$. La presencia de los géneros Parametriocnemus, Cricotopus f4, Cricotopus sp3, Cricotopus (Isocladius), Oliveiriella, Onconeura, Alotanypus y Pentaneura se asoció a temperaturas bajas, alto oxígeno disuelto y baja conductividad, mientras que Cricotopus sp., Rheotanytarsus, Tanytarsus y Chironomus se asociaron con alta conductividad y bajas concentraciones de oxígeno disuelto. El análisis RELATE mostró que las características ambientales locales determinan la composición de la comunidad de quironómidos. Conclusiones: La similitud entre los factores ambientales locales se correlacionó fuertemente con la similitud entre los conjuntos de Chironomidae, especialmente con variables como la concentración de oxígeno, el $\mathrm{pH}$ y la conductividad, cuyas variables están altamente correlacionadas con el uso de la tierra y la vegetación dominante en las cuencas hidrográficas muestreadas.

Palabras clave: Andes tropicales; variables ambientales; patrones de diversidad.

\section{REFERENCES}

Acosta, R., \& Prat, N. (2010). Chironomid assemblages in high altitude streams of the Andean region of Peru. Fundamental and Applied Limnology, 177(1), 57-79. DOI: $10.1127 / 1863-9135 / 2010 / 0177-0057$

Armitage, P.D., Cranston, P.S., \& Pinder, C.V. (1995). The Chironomidae Biology and ecology of non-biting midges. London, United Kingdom: Chapman \& Hall.

Ashe, P., Murray, D.A., \& Reiss, F. (1987). The zoogeographical distribution of Chironomidae (Insecta: Diptera). Annales de Limnologie, 23(1), 27-60. DOI: 10.1051/limn/1987002

Benjumea, C., \& Wills, Á. (2007). Evaluación de la estratificación térmica y su relación con el oxígeno disuelto del agua en la ciénaga Cachimbero, municipio de Cimitarra, Santander. Revista Facultad de Ingeniería, $41,48-65$.

Borcard, D., Gillet, F., \& Legendre, P. (2011). Numerical Ecology with R. Cham, Switzerland: Springer. DOI: 10.1007/978-3-319-71404-2

Braak Ter, C., \& Barendregt, P. (1998). CANOCO. Reference and Manual user's guide to Canoco for Windows: Software for Canonical Community Ordination (Version 4). New York, United States of America: Microcomputer power.

Briceño, J., Iniguez-Gallardo, V., \& Ravera, F. (2016). Factores que influyen en la apreciación de servicios ecosistémicos de los bosques secos del sur del Ecuador. Revista Ecosistemas, 25(2), 46-58. DOI: 10.7818/ RE.2014.25-2.00

Caleño, Y., Rivera-Rondon, C.A., \& Ovalle, H. (2018). Hábitos alimentarios de quironómidos (Diptera: chironomidae) en Lagos del Páramo de Chingaza, Colombia. Revista de Biologia Tropical, 66(1), 136148. DOI: $10.15517 /$ rbt.v66i1.28951

Chao, A., Gotelli, N.J., Hsieh, T.C., Sander, E.L., Ma, K.H., Colwell, R.K., \& Ellison, A.M. (2014). Rarefaction and extrapolation with Hill numbers: A framework for sampling and estimation in species diversity studies. Ecological Monographs, 84(1), 45-67. DOI: $10.1890 / 13-0133.1$

Chao, A., \& Jost, L. (2015). Estimating diversity and entropy profiles via discovery rates of new species. 873-882. DOI: 10.1111/2041-210X.12349

Clarke, K., \& Gorley, R. (2006). PRIMER v6: User Manual/Tutorial (Plymouth Routines in Multivariate Ecological Research). PRIMER-E. Plymouth, United Kingdom: Plymouth Marine Laboratory.

Clarke, R., \& Warwick, R. (1994). Change in marine communities: an approach to statistical analysis and interpretation. Plymouth, United Kingdom: Primer-E Ltd. 
Da Silva, F.L., \& Ekrem, T. (2016). Phylogenetic relationships of nonbiting midges in the subfamily Tanypodinae (Diptera: Chironomidae) inferred from morphology. Systematic Entomology, 41(1), 73-92. DOI: $10.1111 /$ syen.12141

Dos Santos, D.A., Molineri, C., Nieto, C., Zuñiga, M.C., Emmerich, D., Fierro, P., ... Domínguez, E. (2018). Cold/Warm stenothermic freshwater macroinvertebrates along altitudinal and latitudinal gradients in Western South America: A modern approach to an old hypothesis with updated data. Journal of Biogeography, 45(7), 1571-1581. DOI: 10.1111/jbi.13234

Encalada, A., Alexander S. Flecker, N., Poff, L., Suárez, E., Herrera, G., Ríos-Touma, B., ... Anderson, E. (2019). A global perspective on tropical montane rivers. Sience, 365, 1124-1129. DOI: 10.1126/science.aax1682

Epler, J.H. (2001). Identification Manual for the larval Chironomidae (Diptera) of North and South Carolina. A guide to the taxonomy of the midges of the Southeastern United States, including Florida. Palatka, United States of America: North Carolina Department of Environment and Natural Resources.

Escribano-Ávila, G. (2016). El bosque seco neotropical de la provincia Ecuatoriana: un pequeño gran desconocido. Ecosistemas: Revista Cientifica y Técnica de Ecología y Medio Ambiente, 25(2), 1-4. DOI: 10.7818/re.2014.25-2.00

Hamerlik, L., da Silva, F.L., \& Jacobsen, D. (2019). Chironomidae (Insecta: Diptera) of Ecuadorian Highaltitude Streams: A Survey and Illustrated Key. Florida Entomologist, 101(4), 663-675. DOI: 10.1653/024.101.0404

Hanson, P., Springer, M., \& Ramirez, A. (2010). Introducción a los grupos de macroinvertebrados acuáticos. Revista de Biología Tropical, 58(4), 3-37.

Harper, D.M., \& Phillips, G. (1992). Eutrophication of Freshwaters: Principles, Problems and Restoration. London, United Kingdom: Chapman \& Hall.

Hsieh, T.C., Ma, K.H., \& Chao, A. (2016). iNEXT: An R package for rarefaction and extrapolation of species diversity (Hill numbers). Hsin-Chu, Taiwan: Institute of Statistics, National Tsing Hua University.

Jacobsen, D. (2003). Altitudinal changes in diversity of macroinvertebrates from small streams in the Ecuadorian Andes. Archiv Für Hydrobiologie, 158(2), 145-167. DOI: 10.1127/0003-9136/2003/0158-0145

Jollife, I.T., \& Cadima, J. (2016). Principal component analysis: A review and recent developments. Philosophical Transactions of the Royal Society A: Mathematical, Physical and Engineering Sciences, 374(2065), 1-16. DOI: 10.1098/rsta.2015.0202

Lencioni, V., Cranston, P.S., \& Makarchenko, E.A. (2018). Recent advances in the study of chironomidae: An overview. Journal of Limnology, 77(1), 1-6. DOI: 10.4081/jlimnol.2018.1865

López, R.H., \& Talero, G.M. (2015). Densidad Larval de Chironomidae (Insecta: Diptera) en un Meandro del Río Bogotá (Cajicá, Colombia) Durante La Niña 2011. Revista Facultad de Ciencias Básicas, 11(1), 48-67. DOI: $10.18359 / \mathrm{rfcb} .381$

Manson, J.R., Wallis, S.G., \& Hope, D. (2001). A conservative semi-Lagrangian transport model for rivers with transient storage zones. Water Resources Research, 37(12), 3321-3329.

Minaudo, C., Meybeck, M., Moatar, F., Gassama, N., \& Curie, F. (2015). Eutrophication mitigation in rivers: 30 Years of trends in spatial and seasonal patterns of biogeochemistry of the Loire River (1980-2012). Biogeosciences, 12(8), 2549-2563. DOI: 10.5194/ bg-12-2549-2015

Mittermeier, R., Myers, N., Thomsen, J., da Fonseca, G., \& Olivieri, S. (1998). Biodiversity Hotspots and Major Tropical Wilderness Areas: Approaches to Setting Conservation Priorities. Conservation Biology, 12(3), 516-520. DOI: 10.1046/j.1523-1739.1998.012003516.x

Ossa, P., Prat, N., Castaño, G., Ospina, E., Rodriguez, G., \& Rivera, F. (2018). Genus 1 sp . 2 (Diptera: Chironomidae): The Potential Use of its Larvae as Bioindicators. Environmental Analysis \& Ecology Studies, 4(3), 1-10. DOI: 10.31031/EAES.2018.04.000589

Oviedo-Machado, N., \& Reinoso-Flórez, G. (2018). Ecological aspects of Chironomidae larvae (Diptera) of the Opia river (Tolima, Colombia). Revista Colombiana de Entomología, 44(1), 101-109. DOI: 10.25100/ socolen.v44i1.6546

Paggi, A. (2003). Los Quironómidos (Diptera) y su empleo como bioindicadores. Biología Acuática, 21, 50-57.

Prat, N., Acosta, R., Villamarín, C., \& Rieradevall, M. (2018). Guia para el reconocimiento de las larvas de Chironomidae (Diptera) de los ríos Altoandinos de Ecuador y Perú. Clave para la determinación de los principales morfotipos larvarios. Barcelona, Spain: Grupo de Investigación F.E.M.

Prat, N., \& García-Roger, E. (2018). Are there so many congeneric species of chironomid larvae in a small stream? Journal of Limnology, 77(s1), 65-80. DOI: 10.4081/jlimnol.2018.1757

Prat, N., Paggi, A., Ribera, C., Acosta, R., Ríos-Touma, B., Villamarín, C., ... Rieradevall, M. (2018). The Cricotopus (Oliveiriella) (Diptera: Chironomidae) of the High Altitude Andean Streams, with Description of a New Species, C. (O.) rieradevallae. Neotropical Entomology, 47(2), 256-270. DOI: 10.1007/ s13744-017-0548-5 
Prat, N., Rieradevall, M., Acosta, R., \& Villamarín, C. (2011). Guía para el reconocimiento de las larvas de Chironomidae (Diptera) de los ríos Altoandinos de Ecuador y Perú. Clave para la determinación de los géneros. Barcelona, Spain: Grupo de Investigación F.E.M., Departamento de Ecología Universidad de Barcelona.

Prat, N., Ríos-Touma, B., Acosta, R., \& Rieradevall, M. (2009). Los macroinvertebrados como indicadores de calidad de las aguas. In E. Domínguez \& H. Fernández (Eds.), Macroinvertebrados bentónicos sudamedamericanos. Sistemática y Biología ( $1^{\text {st }}$ ed., pp. 631-654). Argentina: Fundación Miguel Lillo.

Ríos-Touma, B., Acosta, R., \& Prat, N. (2014). The Andean Biotic Index (ABI): revised tolerance to pollution values for macroinvertebrate families and index performance evaluation. Revista de Biología Tropical, $62,249-273$.

Ríos-Touma, B., \& Ramírez, A. (2019). Multiple stressors in the Neotropical region: Environmental impacts in biodiversity hotspots. In S. Sabater, A. Elosegi, \& R. Ludwing (Eds.), Multiple stressors in river ecosystems: Status, Impacts and Prospects for the Future (pp. 205-220). Amsterdam, Netherlands: Elservier.

Roback, S.S., \& Coffman, W.P. (1983). Results of the Catherwood Bolivian- Peruvian Altiplano Expedition Part II. Aquatic Diptera including Montane Diamesinae and Orthocladiinae (Chironomidae) from Venezuela. Proceedings of the Academy of Natural Sciences of Philadelphia, 135, 9-79.

Ruiz-Moreno, J., Ospina-Torres, R., Gómez-Sierra, H., \& Riss, W. (2000). Guía para la identificación genérica de larvas de quironómidos (Diptera: Chironomidae) de la sabana de Bogotá. III. Subfamilias Tanypodinae y Diamesinae. Caldasia, 22(1), 34-60.

Ruíz-Moreno, J., Ospina-Torres, R., \& Riss, W. (2000). Guía para la identificación genérica de larvas de quironómidos (Diptera: Chironomidae) de la sabana de Bogotá. II. Subfamilia Chironominae. Caldasia, 22(1), 15-33.
Scheibler, E., Pozo, V., \& Paggi, A. (2008). Distribución espacio-temporal de larvas de Chironomidae (Diptera) en un arroyo andino (Uspallata, Mendoza, Argentina). Revista de La Sociedad Entomológica Argentina, 67(3-4), 45-58.

Sierpe, C., \& Sunico, A. (2019). Familia Chironomidae (Orden Díptera) utilizada como bioindicador para la determinación de calidad ambiental de la cuenca del Río Gallegos (Santa Cruz, Argentina). Informes Científicos Técnicos - UNPA, 11(2), 92-105. DOI: 10.22305/ict-unpa.v11i2.789

Sierra, R. (1999). Propuesta preliminar de un sistema de clasificación de vegetación para el Ecuador continental. Quito, Ecuador: Proyecto INEFA/GEF y EcoCiencia.

Verberk, W., Bilton, D., Calosi, P., \& Spicer, J. (2011). Oxygen supply in aquatic ectotherms: Partial pressure and solubility together explain biodiversity and size patterns. Ecology, 98(8), 1565-1572. DOI: 10.1002/ecy. 1730

Villamarín, C., Prat, N., \& Rieradevall, M. (2014). Caracterización física, química e hidromorfológica de los ríos altoandinos tropicales de Ecuador y Perú. Latin American Journal of Aquatic Research, 42(5), 10721086. DOI: $10.3856 /$ vol42-issue 5-fulltext-12

Villamarín, C., Rieradevall, M., \& Prat, N. (2020). Macroinvertebrate diversity patterns in tropical highland Andean rivers. Limnetica, 39(2), 677-691. DOI: $10.23818 /$ limn.39.44

Villamarín, C., \& Villamarín-Cortez, S. (2018). La calidad ecológicay conservación de los ríos de la provincia de El Oro. In J. Valdiviezo-Rivera, C. GarzónSantomaro, D. Inclán, D. González, \& J. Mena-Jaén (Eds.), Ecosistemas dulceacuícolas de la provincia de El Oro: Peces y macroinvertebrados acuáticos como indicadores biológicos del Páramo al Manglar (pp. 215-249). Ecuador: GADPEO INABIO. 